\section{The metal production at Düzen Tepe (Southwest Turkey): an archaeological and archaeometric study}

\author{
Kim Vyncke, ${ }^{1}$ Branko Mušič, ${ }^{2}$ \\ Patrick Degryse, ${ }^{3}$ Marc Waelkens \\ 'Sagalassos Archaeological Research \\ Project, Department of Archaeology, \\ Leuven, Belgium; ' ${ }^{2}$ earh d.o.o., Maribor, \\ Slovenia; ${ }^{3}$ Center for Archaeological \\ Sciences, Division of Geology, Katholieke \\ Universiteit Leuven, Belgium
}

\section{Abstract}

At the Classical-Hellenistic settlement at Düzen Tepe (SW Turkey), magnetite particles were observed in the majority of the excavation contexts and a considerable amount of metal production waste and metal objects was found in a wide variety of archaeological contexts. In order to find out the origin of the magnetite ore and to determine whether or not the ores, production waste and objects all originated from local metal production activities, a series of archaeological and archaeometric studies were executed. A petrographic study of production waste samples and X-ray fluorescence analysis of production waste and a magnetite ore sample indicated that indeed magnetite was used in the process from which the waste samples resulted. Several inherent characteristics of the magnetite sample used in this study, are likely reflected in the production waste samples. Through a combination of geomagnetic survey and archaeological test soundings a couple of areas probably related to iron production activities could be determined. One location was identified as an area for ore preparation. Although mutual links could not be determined for all three find categories related to metal production (ore, production waste and objects), the study yielded sufficient arguments to assume that metal was produced locally, local magnetite sources were exploited for that reason and at least part of the metal finds from the excavations resulted from that local production.

\section{Introduction}

Düzen Tepe is a Classical-Hellenistic site located in SW Turkey at $1.8 \mathrm{~km}$ from antique Sagalassos (Figure 1). The settlement's remains are located on two promontories, enclosed to the North by Mount Zencirli (1782 m). Since its discovery in 2005 the site has been the subject of archaeological survey, test soundings and large-scale excavations, geophysical survey and a series of interdisciplinary investigations. The archaeological remains excavated so far are those of singleor multi-roomed (courtyard) buildings (Figure 1) constructed with relatively simple techniques, involving walls with a fieldstone soccle and a wattle-and-daub upper structure, and the remains of two largely destroyed (pottery?) kilns (Vanhaverbeke et al., 2010). Apart from one isolated more monumental building, all architectural remains are quite basic and there is no indication for an organised pottery production similar to the later (i.e. Augustan; Poblome, 1999) Red Slip Ware production in partly contemporary Sagalassos.

During surveys and excavations between 2005 and 2008, fragments of magnetite ore, metal slag and a variety of metal objects appeared in different types of archaeological layers, namely waste-, occupational- and postoccupational contexts. With these finds, several questions arose, which could possibly drastically change our view on this seemingly very rudimentary settlement. First of all, the origin of the omnipresent magnetite ore needed to be determined, in order to find out if this omnipresence of ores was the result of a local acquisition or of a major import. Secondly, it needed to be found out whether or not the ores, slags and objects could all be linked to the different stages of one and the same metal production cycle and thus if the existence of local metallurgic activities could be confirmed.

\section{Materials and Methods}

Since 2006 geomagnetic survey has been carried out at Düzen Tepe with a high resolution caesium magnetometer in closely spaced parallel profiles supported by apparent magnetic susceptibility measurements of top soil, excavated bulk material, limestone building material and in situ remains of ceramic archaeological remains (kilns). The magnetometer Geometrics G-858 that was used in the research attains a resolution of $0.1-0.2 \mathrm{nT} / \mathrm{m}$ in measuring the total field density with an acquisition speed of $0.2 \mathrm{~s}$. In practice this allows readings to be taken while walking at a regular speed in the direction of the profile at intervals of $15 \mathrm{~cm}$. The distance between the parallel magnetic profiles measured $0.5 \mathrm{~m}$. The magnetogram portray the values of total magnetic field gradients calculated onto a grid of $0.25 \times 0.25 \mathrm{~m}$ (Figure 2).

The values of apparent susceptibility of the top soil at the central plateau are within the limits between 1.3 and $6.6 \times 10^{-3} \mathrm{SI}$ (Kappameter $K T-5)$, with a mean value of $4.6 \times 10^{-3} \mathrm{SI}$ and standard deviation of $1.1 \times 10^{-3} \mathrm{SI}$ while the sus-
Correspondence: Kim Vyncke, Sagalassos Archaeological Research Project, Department of Archaeology, Katholieke Universiteit Leuven, Theresiastraat 21, 3000 Leuven, Belgium.

Tel. +32.16324721 - Fax: +32.16325094 .

E-mail: kim.vyncke@gmail.com

Acknowledgments: Steven Luypaers and Elvira Vassilieva are kindly thanked for conducting the chemical analyses. An anonymous reviewer is greatly acknowledged for his comments, which helped to improve the quality of this paper.

Funding: this study is part of the scientific research executed in the framework of the Sagalassos Archaeological Research Project. The research was supported by the Belgian Programme on Interuniversity Poles of Attraction (IAP 6/22) and the Research Fund of the K.U.Leuven (BOF-GOA 07/02), next to project G.0421.06 of the Fund for Scientific Research, Flanders (FW0). M. Waelkens received a 'Methusalem grant' from the Flemish Ministry for Science Policy.

Key words: metal production, geomagnetic survey, test soundings, petrography, X-ray fluorescence.

Citation: Vyncke K, Mušič B, Degryse P, Waelkens M, 2014. The metal production at Düzen Tepe (Southwest Turkey): an archaeological and archaeometric study. In: RH Tykot (ed.), Proceedings of the $38^{\text {th }}$ International Symposium on Archaeometry - May $10^{\text {th }}-14^{\text {th }} 2010$, Tampa, Florida. Open Journal of Archaeometry 2:5461.

Presented at the $38^{\text {th }}$ International Symposium on Archaeometry - May $10^{\text {th }}-14^{\text {th }} 2010$, Tampa, Florida.

This work is licensed under a Creative Commons Attribution 3.0 License (by-nc 3.0).

(C) Copyright K. Vyncke et al., 2014

Licensee PAGEPress, Italy

Open Journal of Archaeometry 2014; 2:5461

doi:10.4081/arc.2014.5461

ceptibility of top soil at terraces are even higher with the mean value of $9.9 \times 10^{-3} \mathrm{SI}$ and standard deviation of $1.7 \times 10^{-3} \mathrm{SI}$. The susceptibility of the limestone material, used for the foundations of structures, measures only $0.1-0.2 \times$ $10^{-3} \mathrm{SI}$. A consequence of the large differences in the magnetic susceptibility between archaeological architectural remains made of limestone and the top soil are the strong magnetic anomalies of the induced magnetisation, and thus also a clear appearance of architectural remains on the magnetograms (Figure 2). Next to the identification of probable architectural remains - which delivered excellent results given the high iron oxide minerals content of the soil compared to the iron-poor limestone used as a building material for the soc- 
cles - the geophysical survey results were used to identify magnetic anomalies which could be related to either pyrotechnical archaeological contexts, craft activities or possible geological sources of enhanced magnetic background of the site. At this point it is evident that besides a significantly higher magnetic background at the pyrotechnical archaeological contexts, some isolated archaeological objects made of burned clay, frequently encountered in such archaeological context like ceramic floors and kilns, can be recognised on magnetograms on the basis of their strong thermoremanent magnetisation and mean magnetic susceptibility of $8.6 \times 10^{-3} \mathrm{SI}$ and $20.3 \times 10^{-3} \mathrm{SI}$, respectively.

During the 2009 excavation campaign, two test soundings $(5 \times 5 \mathrm{~m})$ were executed in an area with a very high thermoremanent magnetisation, which was thought to be an orevein, to identify the latter's origin. Another test sounding was executed in an area where a large number of these magnetite fragments as well as other minerals - were found at the surface, to find out if there was an archaeological or geological reason for the large concentrations of minerals in this particular area. Furthermore, the area studied by means of geophysical survey was largely extended during the same excavation campaign in order to further identify the architectural remains and geomagnetic anomalies on the complete plateau. After the 2009 excavation campaign, samples of magnetite, slag and some iron objects were collected as surface finds and from various excavation contexts, and subjected to chemical analysis (X-ray fluorescence, using a Panalytical Axios Advanced wavelength dispersive XRF for the Düzen Tepe samples and a Siemens SRS 3000 for the Sagalassos samples) and a petrographic study. The chemical content and petrography of all samples taken at Düzen Tepe were mutually compared to confirm or deny a local production chain. Finally, the results from both studies were compared to the results of earlier studies on metal production waste from Sagalassos, to identify similarities or differences between the samples of Düzen Tepe and those of its partly-contemporary neighbouring city.

\section{Results}

Firstly, in both test soundings executed in 2009 in the area of the presumed ore vein - as interpreted from the geophysical survey results (see above) - a layer of very compact red clay ( $0.3 \mathrm{~m}$ thick on average) was identified. Whereas only about $0.7 \times 0.3 \mathrm{~m}$ of the layer was excavated in test sounding I, compared to several square meters in sounding II, the nearly identical appearance of the red clay layer in both test soundings indicated that this strati- graphical unit extends over a large distance. This non-archaeological layer included a rather large amount of mineral ores (generally a couple of millimeters to a couple of centimeters large), a.o. magnetite and grossular.

Within the third test sounding, executed on the basis of surface finds (see supra), a yellow, sandy layer was discovered at a depth of about $0.8 \mathrm{~m}$ (Figure 3 ). The layer, which actually consists of dozens of millimeter thick layers of the same sediment, turned out to be highly mag- netic and included a large amount of extremely fragmented magnetite. As the layer was only present over an area of $0.7 \times 0.5 \mathrm{~m}$ (width) within the SW corner of the excavation trench and expandings into the eastern ( $0.15 \mathrm{~m}$ thick) and southern (equal thickness) profile, the excavated part is probably only the westernmost part of this stratigraphical unit.

Within the extended geophysical survey results, a division could be made between 3 kinds of areas with high magnetisation
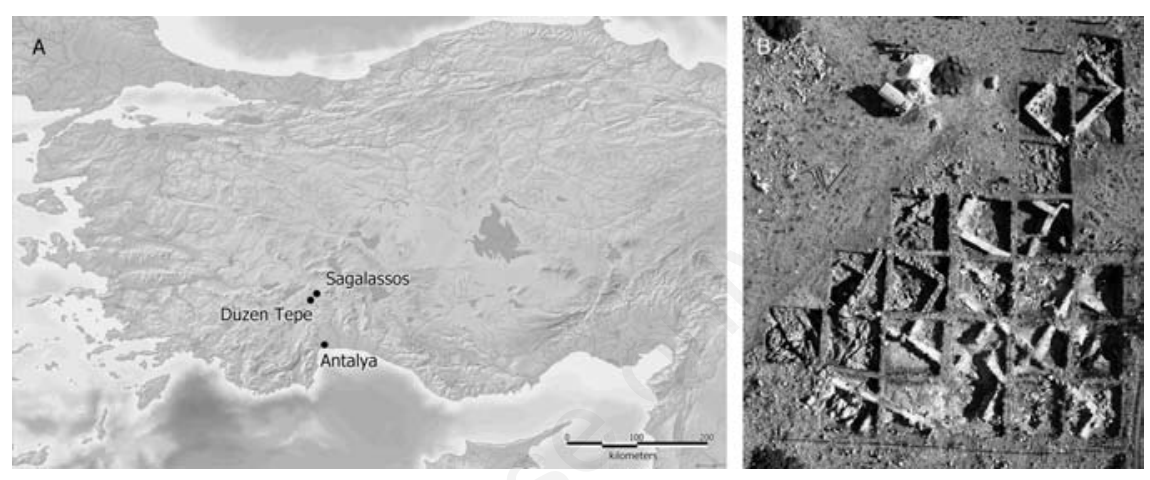

Figure 1. Location of Düzen Tepe in Turkey (A) and aerial view on one of the excavation trenches $(\mathrm{B})$.

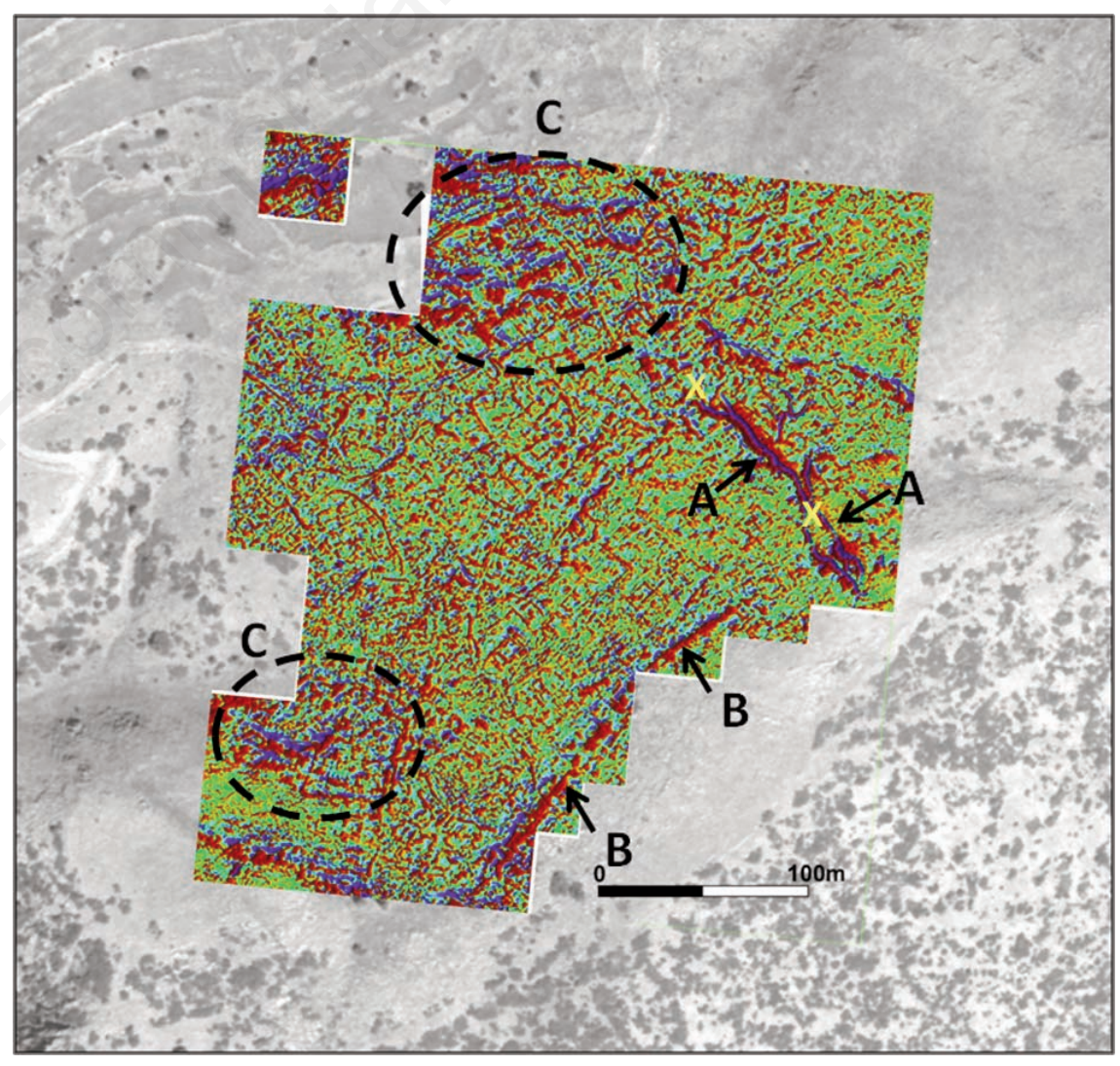

Figure 2. Magnetogram of the central part of the Düzen Tepe plateau. Red is high magnetism while green is low magnetism. Test soundings I and II are indicated with yellow $\mathrm{x}$-marks. A) is a possible ore vein, recognised as a concentration of magnetite in excavation; B) is a possible ore vein, not excavated; and C) is an area of diffuse magnetisation, a possible ore processing area. 
(Figure 2). The first area, indicated as A, was already known before the excavation campaign and is the area of very high remanent magnetisation interpreted as a possible ore vein. The second area, indicated as B, are a series of linear high magnetisation lines. A last group, group C, consists of two areas of high induced or remanent mineralisation. These areas, however, show no linear traces of magnetism, but are larger areas with a diffuse pattern of high magnetism.

The petrography (polished sections) of 3 slag samples (SA08PD62-70-78) is highly similar. Dendritic wuestite is detected in a matrix of forsterite and fayalite. There is a frequent occurrence of magnetite and some metallic iron is present. All samples show large pores. The polished section of one sample (SA08PD70; Figure 4) contains a cluster of magnetite.

In the polished section, an iron bloom sample (SA08PD82) consists mainly of spongy metallic iron. The surface of the sample is weathered to goethite-limonite. Magnetite and wuestite occur sporadically, the latter mainly at the edge of the sample.

Elemental analysis values of slag, bloom and magnetite ore samples obtained by X-ray fluorescence (Table 1) show interesting similarities and differences. All slag samples show high to very high $\mathrm{CaO}, \mathrm{Al}_{2} \mathrm{O}_{3}, \mathrm{Ni}$, Cu contents and low contents in $\mathrm{Fe}_{2} \mathrm{O}_{3}$. One slag sample (SA08PD69) has an extremely low $\mathrm{Fe}_{2} \mathrm{O}_{3}$ content, yet much higher contents of $\mathrm{SiO}_{2}, \mathrm{Al}_{2} \mathrm{O}_{3}$, $\mathrm{NaO}_{2}, \mathrm{~K}_{2} \mathrm{O}, \mathrm{TiO}_{2}, \mathrm{Zr}, \mathrm{Cr}$ and Th compared to the other slag samples. For one slag sample (SA09PD167), the high Cu and Sn contents are remarkable. The bloom sample has a high $\mathrm{Fe}_{2} \mathrm{O}_{3}$ content, whereas most other element concentrations are lower. In comparison to the slag samples, the magnetite ore has elevated concentrations for $\mathrm{TiO}_{2}, \mathrm{MnO}, \mathrm{MgO}, \mathrm{Cr}$ and $\mathrm{Ni}$, and lower contents for $\mathrm{SiO}_{2}, \mathrm{NaO}_{2}, \mathrm{~K}_{2} \mathrm{O}$ and $\mathrm{P}_{2} \mathrm{O}_{5}$. The $\mathrm{Pb}$ content of the samples is low and excludes the possibility of $\mathrm{Pb}$ isotope analysis of the ore and possible resulting objects.

In comparison to X-ray fluorescence analysis of 14 slag and bloom samples from Sagalassos (Table 2), dated between the $1^{\text {st }}$ and $7^{\text {th }}$ century $\mathrm{AD}$, most element concentrations of the Düzen Tepe samples are quite different from those of its neighbouring city. Concentrations of elements like $\mathrm{Pb}, \mathrm{MgO}, \mathrm{Cr}$ are higher in the Sagalassos samples, whereas concentrations of $\mathrm{TiO}_{2}$ are lower.

\section{Discussion}

The clay-rich layer identified in both test soundings in the area of the presumed ore vein can be interpreted as a rudimentary plac- er-deposit (Rapp, 2002). The heavy minerals contained within the clay (magnetite, grossular, etc.) can be interpreted as the sole leftovers of an older, now completely eroded, geological formation. Within the karstic topography of the Düzen Tepe plateau, these heavy minerals likely were embedded in the clay that filled depressions and potholes in the lime- stone bedrock and thus formed small scale placer deposits. In addition, given the shape of the group B magnetic areas and their location in natural depressions of the plateau, it is probable that these areas can be identified as placer deposits as well.

Within the first two test soundings, no geological or archaeological features were found

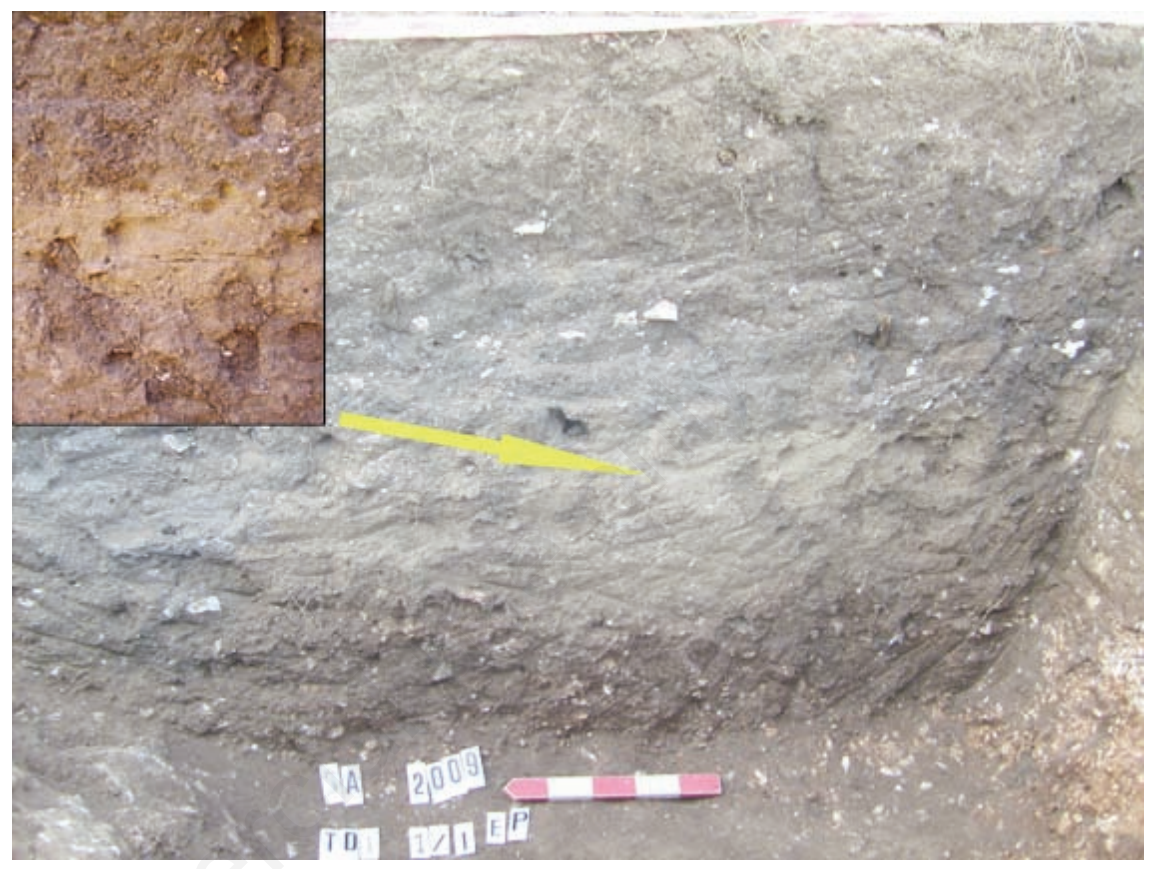

Figure 3. The eastern profile of test sounding III with detail of the yellow layer of very fragmented magnetite.

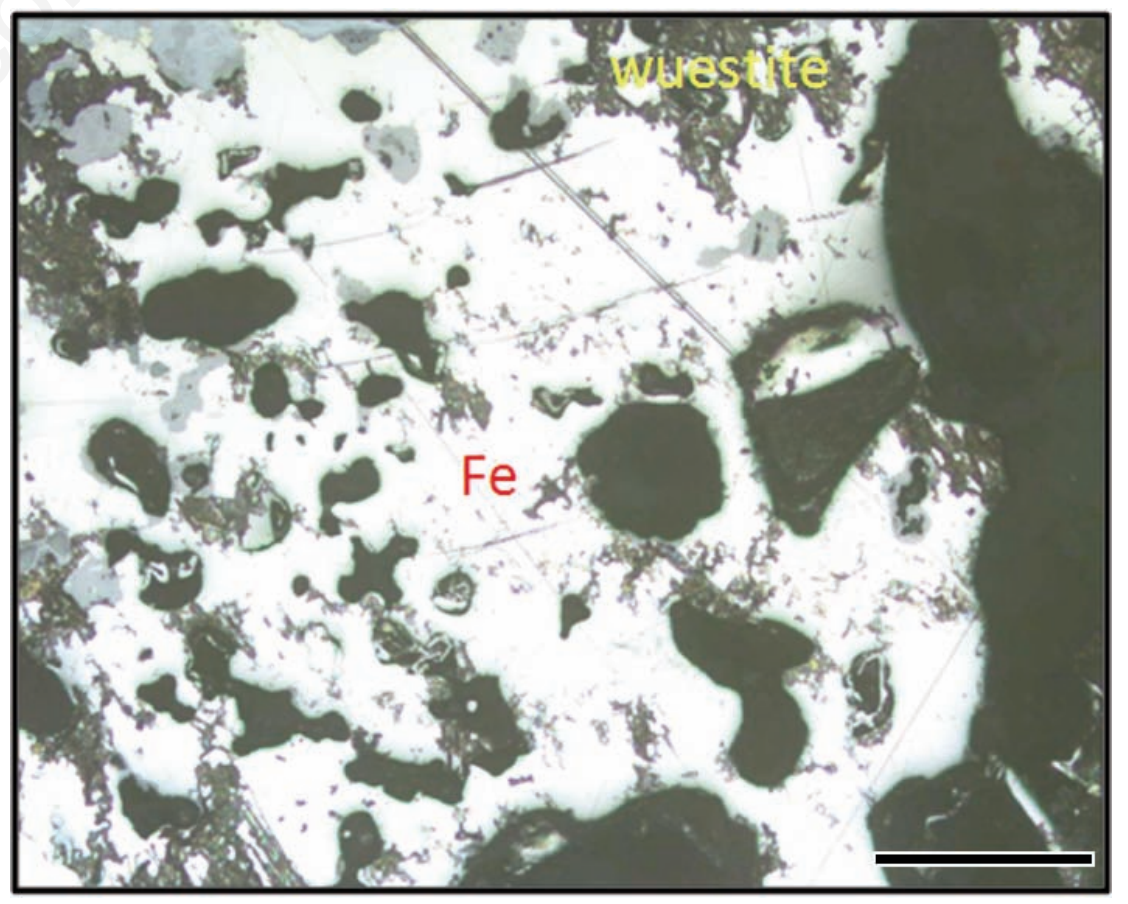

Figure 4. Polished section of bloom sample SA08PD70. Scale is $500 \mu \mathrm{m}$. 
that have the capacity to explain the high magnetic signal on the magnetogram. It is possible that an ore vein or an other geological entity causing the high magnetism is located beneath the bedrock level that was excavated.

The archaeological contexts identified within the third test sounding are very different from those of the previously described test soundings. To ascertain a maximum smelt of a load of magnetite, the ore needs to be crushed to a very fine grain. Therefore, the yellow layer is probably a waste layer of a site where ore was crushed and probably also washed. The observations from the polished sections, namely the presence of magnetite and wuestite, in itself indicates that indeed magnetite was used in the production process from which the waste samples origin. The yellow layer containing a large amount of highly fragmented magnetite was interpreted here as the refuse of an ore processing site. Given the fact that no tools or mechanical installations were found within the excavation area and given the observations on the possible extent of the layer, it is likely that an ore processing site was located to the NE of the test sounding and that the layer is the result of flow-off processes. The fact that the layer actually consists of a large amount of identical horizontal layers, confirms this flow-off theory.

On the magnetogram, the areas indicated as $\mathrm{C}$ are also thought to be metal-processing areas. Their shape could have been caused by ore-processing in this area or by other metallurgy-related processes.

The metal slag samples have similar elemental concentrations and the fact that some values - e.g. $\mathrm{CaO}$ - are within the same range of the magnetite sample, could indicate that they reflect element values inherent to the magnetite ore. The difference in $\mathrm{TiO}_{2}$ content between the production waste samples and the magnetite sample, however, may indicate that the source of magnetite used in the production process(es) where the slag results from, is not the same as that of the magnetite sample analysed here, or that the values in the slag reflect a dilution with furnace material, flux and/or fuel. There probably is an influence of fuel and furnace material to a certain extent, as the values of e.g. $\mathrm{K}_{2} \mathrm{O}, \mathrm{Al}_{2} \mathrm{O}_{3}, \mathrm{MgO}$ and $\mathrm{CaO}$ are somewhat high in most slag samples, yet not to extreme proportions. The relatively high $\mathrm{SiO}_{2}$ contents within some of the slag samples could indicate a larger influence of flux (sand) used.

One slag sample (SA08PD69) with the aberrant content of e.g. $\mathrm{SiO}_{2}, \mathrm{Al}_{2} \mathrm{O}_{3}, \mathrm{~K}_{2} \mathrm{O}, \mathrm{TiO}_{2}$, is probably part of a kiln construction rather than an actual metal slag.

The high $\mathrm{Cu}$ and $\mathrm{Sn}$ within slag sample SA09PD167 are likely indicative that also bronze was produced in the context where this sample originates from.

The comparison of the element concentrations in the Düzen Tepe samples and the Sagalassos samples indicates that the ore used in the Sagalassos samples is different from the one used in the Düzen Tepe samples.

Table 1. X-ray fluorescence analysis results on slag, bloom and magnetite ore from Düzen Tepe.

\begin{tabular}{|c|c|c|c|c|c|c|c|c|c|c|}
\hline & $\mathrm{SiO}_{2}(\%)$ & $\mathrm{Al}_{2} \mathrm{O}_{3}(\%)$ & $\mathrm{Fe}_{2} \mathrm{O}_{3}(\mathrm{~T})(\%)$ & $\mathrm{MnO}(\%)$ & $\begin{array}{l}\text { Analyte } \\
\text { Mg0 (\%) }\end{array}$ & $\mathrm{CaO}(\%)$ & $\mathrm{Na}_{2} \mathrm{O}(\%)$ & $\mathrm{K}_{2} \mathrm{O}(\%)$ & $\mathrm{TiO}_{2}(\%)$ & $\mathrm{P}_{2} \mathrm{O}_{5}(\%)$ \\
\hline Detection limit & 0.01 & 0.01 & 0.01 & 0.01 & 0.01 & 0.01 & 0.01 & 0.01 & 0.01 & 0.01 \\
\hline SA08PD070 & 14.34 & 4.89 & 71.75 & 0.18 & 1.02 & 5.51 & 0.63 & $1-10$ & 0.24 & 0.35 \\
\hline SA08PD078 & 26.44 & 7.59 & 52.11 & 0.19 & 1.53 & 8.18 & 0.86 & 2.17 & 0.31 & 0.62 \\
\hline SA08PD069 $9^{\circ}$ & 58.64 & 19.24 & 6.93 & 0.16 & 1.78 & 3.13 & 3.42 & 5.54 & 0.78 & 0.38 \\
\hline SA08PD $166^{\circ}$ & 20.02 & 8.24 & 55.21 & 0.27 & 1.26 & 10.88 & 0.97 & 1.89 & 0.33 & 0.93 \\
\hline SA08PD167 & 13.45 & 3.82 & 70.50 & 0.11 & 0.86 & 9.42 & 0.31 & 0.65 & 0.17 & 0.70 \\
\hline SA08PD085" & 8.87 & 6.21 & 69.44 & 1.29 & 5.13 & 6.94 & 0.05 & 0.08 & 1.94 & 0.05 \\
\hline \multirow[t]{2}{*}{ SA08PD169\$ } & 5.06 & 1.88 & 90.46 & 0.07 & 0.41 & 1.22 & 0.11 & 0.20 & 0.08 & 0.51 \\
\hline & $\mathrm{Zr}(\mathrm{ppm})$ & Cr (ppm) & Co (ppm) & Ni (ppm) & $\mathrm{Cu}(\mathrm{ppm})$ & Sn (ppm) & Tl (ppm) & $\mathrm{Pb}(\mathrm{ppm})$ & Th (ppm) & $\mathrm{U}(\mathrm{ppm})$ \\
\hline $\mathrm{SA08PD070}{ }^{\circ}$ & 99 & 240 & 41 & 270 & 70 & $<1$ & $<0.1$ & $<5$ & 12.9 & 2.6 \\
\hline SA08PD078 & 168 & 260 & 19 & 170 & 420 & 2 & 0.2 & $<5$ & 18.9 & 3.5 \\
\hline SA08PD069 $9^{\circ}$ & 491 & 380 & 15 & 180 & 50 & 2 & 1.6 & 117 & 62.2 & 11.8 \\
\hline SA08PD $166^{\circ}$ & 206 & 280 & 18 & 160 & 280 & 8 & $<0.1$ & 28 & 26 & 5 \\
\hline SA08PD167 $7^{\circ}$ & 87 & 120 & 43 & 180 & 9500 & $>1000$ & $<0.1$ & 22 & 9.6 & 1.9 \\
\hline SA08PD085" & 220 & 1070 & 49 & 410 & 20 & 23 & $<0.1$ & $<5$ & 5.3 & 3.4 \\
\hline SA08PD169§ & 51 & 50 & 54 & 290 & 340 & $<1$ & $<0.1$ & 38 & 4.8 & 0.9 \\
\hline
\end{tabular}

'Slag; "magnetite; \$bloom.

Table 2. X-ray fluorescence analysis results on slag, bloom and magnetite ore from Sagalassos. After Degryse et al. (2003).

\begin{tabular}{|c|c|c|c|c|c|c|c|c|c|c|c|c|c|c|c|}
\hline & $\begin{array}{c}\mathrm{SiO}_{2} \\
(\%)\end{array}$ & $\begin{array}{r}\mathrm{Al}_{2} \mathrm{O}_{3} \\
(\%)\end{array}$ & $\begin{array}{r}\mathrm{FeO} \\
(\%)\end{array}$ & $\begin{array}{r}\mathrm{TiO}_{2} \\
(\%)\end{array}$ & $\begin{array}{r}\mathrm{Mn0} \\
(\%)\end{array}$ & $\begin{array}{r}\mathrm{Mg0} \\
(\%)\end{array}$ & $\begin{array}{l}\mathrm{CaO} \\
(\%)\end{array}$ & $\begin{array}{c}\mathrm{Na}_{2} \mathrm{O} \\
(\%)\end{array}$ & $\begin{array}{l}\mathrm{K}_{2} \mathrm{O} \\
(\%)\end{array}$ & $\begin{array}{r}\mathrm{P}_{2} \mathrm{O}_{5} \\
(\%)\end{array}$ & $\begin{array}{c}\mathrm{Cr} \\
(\mathrm{ppm})\end{array}$ & $\begin{array}{c}\mathrm{Ni} \\
(\mathrm{ppm})\end{array}$ & $\begin{array}{c}\mathrm{Cu} \\
(\mathrm{ppm})\end{array}$ & $\begin{array}{c}\mathrm{Pb} \\
(\mathrm{ppm})\end{array}$ & $\begin{array}{c}\mathrm{Co} \\
(\mathrm{ppm})\end{array}$ \\
\hline $\mathrm{n}$ & 14 & 14 & 14 & 14 & 14 & 14 & 14 & 14 & 14 & 14 & 13 & 13 & 13 & 1 & 1 \\
\hline Minumum & 4.53 & 1.52 & 42.63 & 0.03 & 0.01 & 0.45 & 1.53 & 0.10 & 0.07 & 0.18 & 38 & 57 & 93 & 640 & 74 \\
\hline Maximum & 40.40 & 6.29 & 87.32 & 0.25 & 0.55 & 1.60 & 8.65 & 0.78 & 3.22 & 0.58 & 360 & 240 & 620 & 640 & 74 \\
\hline Median & 17.70 & 3.73 & 65.18 & 0.11 & 0.13 & 0.89 & 4.41 & 0.30 & 0.62 & 0.34 & 120 & 89 & 150 & - & - \\
\hline Mean & 17.33 & 3.70 & 68.83 & 0.13 & 0.17 & 0.95 & 4.71 & 0.33 & 0.85 & 0.35 & 168 & 117 & 236 & - & - \\
\hline SD & 9.30 & 1.46 & 12.25 & 0.07 & 0.15 & 0.37 & 2.53 & 0.18 & 0.85 & 0.13 & 119 & 58 & 174 & - & - \\
\hline
\end{tabular}

n, number of analyses above detection limit. 
Especially the difference in $\mathrm{TiO}_{2}$ concentrations could indicate that two different ore sources were used. On the other hand, there are indications that the production processes from which the Düzen Tepe samples and the Sagalassos samples originated are not identical. Sufficiently large differences within the values of $\mathrm{K}_{2} \mathrm{O}, \mathrm{Al}_{2} \mathrm{O}_{3}$, $\mathrm{MgO}, \mathrm{CaO}, \mathrm{SiO}_{2}$ and $\mathrm{TiO}_{2}$ could indicate a different influence of fluxes, fuels and furnace materials and thus a different production process.

\section{Conclusions}

After various studies of very different nature, several of the research questions can be partly answered. Even though no direct link can be made between all individual parts of the iron production chain (ore, production waste and objects) for which actual evidence has been found at Düzen Tepe, separate links between several parts of the chain could be established. The origin of the magnetite found in nearly all excavation contexts is likely local, as derived from geomagnetic survey and archaeological test soundings indicating the presence of placer deposits. X-ray fluorescence of local production waste samples could offer some arguments for the use of the local magnetite ore for iron production, and the presence of magnetite in the polished sections of a selection of those same production waste samples confirms that likely a magnetite ore source was used. Through geomagnetic survey and archaeological test soundings, areas of probable iron production related activities could be indicated, e.g. one location where magnetite ores may have been crushed and washed. As all necessary aspects of iron production have been identified at Düzen Tepe itself and as several links between individual stages of production could be confirmed, it is highly probable that local ore sources were exploited in local iron production activities. Although except for the presence of bronze artifacts in excavation contexts no other indications were found, X-ray fluorescence analysis of one single slag sample pointed out the existence of local bronze production activities.

Finally, it is likely that (at least) two different ore sources were used for the metal production at Düzen Tepe and in Roman Sagalassos and that the production waste found at these two sites originate from at least two different production processes.

\section{References}

Degryse P, Muchez P, Naud J, Waelkens M, 2003. Iron production at the Roman to Byzantine city of Sagalassos: an archaeometrical case study. in Proc. Archaeometallurgy in Europe, Milan, Italy, pp 133-142.

Poblome J, 1999. Sagalassos red slip ware. Typology and chronology. Brepols, Turnhout, Belgium.

Rapp G, 2002. Archaeomineralogy. SpringerVerlag, Heidelberg, Germany.

Vanhaverbeke H, Waelkens M, Vyncke K, De Laet V, Aydal S, Music B, De Cupere B, Poblome J, Braekmans D, Degryse P, Marinova E, Verstraeten G, Van Neer W, Slapsak B, Medaric I, Ekinci HA, Erbay MO, 2010. The 'Pisidian' culture? The Classical-Hellenistic site at Düzen Tepe near Sagalassus (southwest Turkey). Anatolian Studies 60:105-28. 